\title{
Features and Problems of Function Conservation Project in Fishing Port Facilities
}

\author{
T. Fujita, Y. Yoshizuka, T. Kaneda, M. Fudo, and S. Date
}

\begin{abstract}
A lot of municipalities in Japan have various fishery facilities to be maintained. However, they are facing the problem that the budget and the expert of maintenance are insufficient. In such a background, it is indispensable to understand points of concern at the beginning of planning, to do efficient maintenance management.

In this study, to extract necessary points of concern, both existing management plans and results were analyzed. In consequence, 1) the mooring facilities and the transportation facilities were tendencies maintained by priority. 2) As for the facilities except steel structure were being managed by not preventive maintenance based on the deterioration forecast but conventional corrective maintenance. As the result, it seemed that the procedure of the determination of priority of maintenance and the method of deterioration forecast for not steel structure are desired to be developed.
\end{abstract}

Index Terms-Conservation control, conservation measure, degradation forecast, function conservation plan.

\section{INTRODUCTION}

There are about 2,900 fishing ports throughout Japan and these have great many of existing facilities. The construction of fishing port facilities started with the economic growth period. Now many of them are more than 30 years old and their degradation has been worried, as in [1].

In consideration of the above mentioned, the Fisheries Agency established the fisheries infrastructure management project in April 2008, as in [2]. The controllers of each fishing port, receiving subsidies for this project, are sequentially commencing the formulation of a function conservation plan and conservation construction.

The subsidies for the formulation of the function conservation plan by the said project are due to stop in fiscal 2017 year; the plan formulation has so far been carried out primarily on lodgment fishing ports. In the future, it is projected that plan formulation will be carried out for municipality controlled fishing ports.

However, in these fishing ports, restrictions on the budget of the municipalities that control them and a shortage of professional engineers involved in conservation and control have become major problems.

In this regard, in order to proceed with the formulation of the function conservation plan, it was necessary to collect and sort out function conservation plan documents already

Manuscript received December 10, 2013; revised February 26, 2014.

T. Fujita and Y. Yoshizuka are with Fisheries Infrastructure Development Center, Japan (e-mail: t-fujita@fidec.or.jp).

T. Kaneda is with Fisheries Research Agency, National Research Institute of Fisheries Engineering, Japan.

M. Fudo is with Fisheries Agency, Fisheries Infrastructure Division, Construction Division.

S. Date is with Tokai University, Japan. formulated and carry out deliberations on current features and problems. This discussion reports features and problems of the function conservation plan.

\section{METHOD}

\section{A. Formulated Function Conservation Plan}

255 targeted function conservation plans were formulated and submitted to the Fisheries Agency in July 2012. The number of designated fishing ports as of April 1, 2013 amounted to 2,909, as in [3], and the number of analyzed fishing ports is a little less than $10 \%$. Particular feature is, there are plenty of fishing ports of class 2 (see Table I).

TABLE I: NUMBER OF TARGETED FISHING PORTS AND DESIGNATED FISHING PORTS

\begin{tabular}{|l|c|c|c|}
\hline $\begin{array}{c}\text { Class of } \\
\text { fishing port }\end{array}$ & $\begin{array}{c}\text { Number of analyzed } \\
\text { port A }\end{array}$ & $\begin{array}{c}\text { Number of designated } \\
\text { port g port B* }\end{array}$ & A/B \\
\hline Class 1 & 70 & 2,179 & 0.03 \\
\hline Class 2 & 113 & 517 & 0.22 \\
\hline Class 3 & 38 & 101 & 0.38 \\
\hline Specific class 3 & 8 & 13 & 0.62 \\
\hline Class 4 & 26 & 99 & 0.26 \\
\hline Total & 255 & 2,909 & 0.09 \\
\hline *As of April 1,2013 & \multicolumn{4}{|l}{} \\
\hline
\end{tabular}

TABLE II: CONTENT OF FUNCTION CONSERVATION PLAN

\begin{tabular}{|c|c|}
\hline Item & Content \\
\hline \multicolumn{2}{|l|}{ 1) Facilities current survey sheet } \\
\hline (1)Facilities 'upgrading conditions & $\begin{array}{l}\text { Up grading condition up to the time of function } \\
\text { conservation plan formulation from up grading the } \\
\text { facilities }\end{array}$ \\
\hline (2)Facilities control situation & Actual control results, problems on control \\
\hline \multicolumn{2}{|c|}{ 2) Function conservation counter measures } \\
\hline (1) Simplified survey result & $\begin{array}{l}\text { Scale of facilities' transformation, degree of aging, } \\
\text { degree of soundness, whether conservation } \\
\text { countermeasure is necessary or not }\end{array}$ \\
\hline (2)Function diagnostic results & $\begin{array}{l}\text { Functional diagnosis (detailed investigation) } \\
\text { implemented according to necessity and whether or } \\
\text { not conservation measures are required }\end{array}$ \\
\hline \multicolumn{2}{|c|}{$\begin{array}{l}\text { 3) Function conservation countermeasures } \\
\text { *In-service period is } 50 \text { y ears after the formulation of a plan }\end{array}$} \\
\hline $\begin{array}{l}\text { (1) Countermeasure construction } \\
\text { method }\end{array}$ & $\begin{array}{l}\text { Comparison/measurement for lifecy cle costs } \\
\text { according to scenarios of conservation } \\
\text { countermeasures during in-service period }\end{array}$ \\
\hline (2)Timing of countermeasures & $\begin{array}{l}\text { Timing of countermeasures during in-service period } \\
\text { for selected scenarios }\end{array}$ \\
\hline (3) Countermeasure costs & $\begin{array}{l}\text { Comparison between countermeasure costs and } \\
\text { total renewal cost during in-service period of } \\
\text { selected scenarios }\end{array}$ \\
\hline (4) Cost reduction effect & $\begin{array}{l}\text { Comparison between countermeasure cost and total } \\
\text { renewal costs during in-service period of selected } \\
\text { scenarios }\end{array}$ \\
\hline (5)Daily control plan & $\begin{array}{l}\text { Categories, frequency, content and so on of } \\
\text { inspections }\end{array}$ \\
\hline
\end{tabular}

B. Analyzed Item

The function conservation plan shall be prepared by 
following the Fisheries Agency's "Prescriptive guide for the formulation of function conservation (Draft), as in [4] (Hereafter called Prescription Guide (Draft)), "Guideline for Fisheries infrastructure facilities stock management (Draft), as in [5] (Hereafter called the formulation of a guideline (Draft) for function conservation formulation), formulated in respect to the content indicated in Table II for each targeted facility. This version sorted out relevant characteristics with regard to facilities requiring conservation measures and selected function conservation measures.

\section{RESULTS AND DISCUSSIONS}

\section{A. Characteristics of Facilities that Require Conservation Measures}

As a result of functional diagnoses, the facilities requiring conservation measures is shown in Fig. 1. About $20 \%$ in of all facilities (Approx. 8,000 facilities) were in a condition that required conservation measures. According to categories, outer facilities (Coastal levee, bank protection) were about $18 \%$ and mooring facilities and transit facilities were about $27 \%$. Percentage points of mooring facilities and transit facilities requiring conservation measures are high. In particular, due to higher frequencies of use in unloading, mooring facilities are inclined to degrade faster.

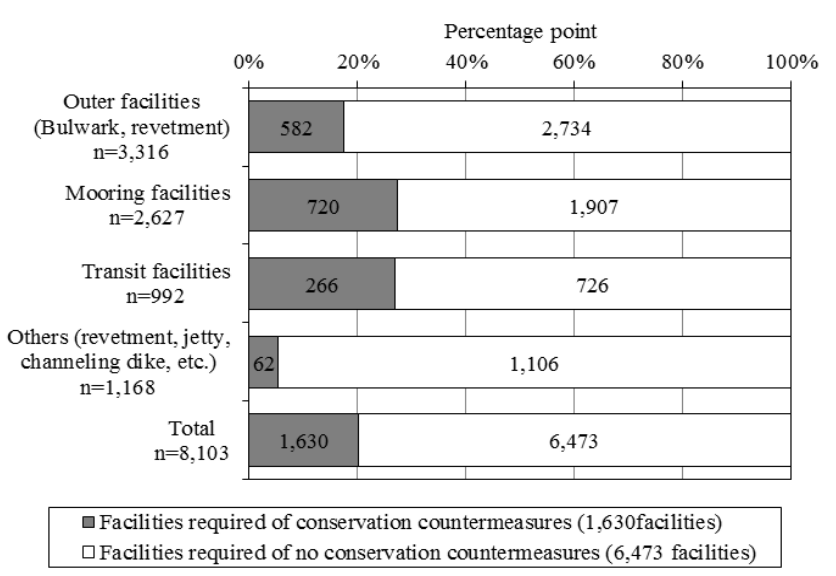

Fig. 1. Rate of facilities required of conservation measures.

For this reason, even in a similar degrading condition, it was considered that the rate of facilities requiring conservation measures tends to be increased due to conservation measures readily be prioritized. Moreover, the importance of facilities utilization shall preliminarily be decided in construction and it is appropriate to preliminary decide of a function conservation level for targeted facilities. It is hoped to decide the importance when utilizing or the like indicated in guidelines (Draft) in reference to function conservation levels to be reevaluated for each facility in the future.

\section{B. The Number of Elapsed Years in Respect to Facilities Requiring Conservation Measures}

\section{1) The number of elapsed years after construction according to structural types of facilities}

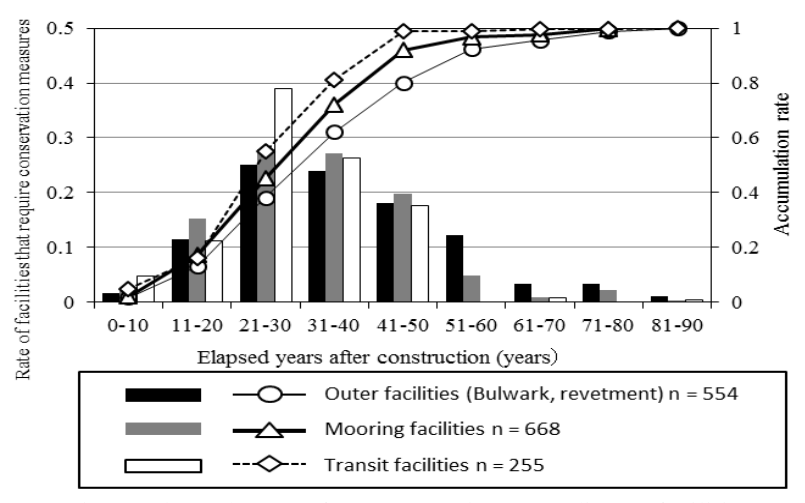

Fig. 2. Elapsed years after construction according to facilities.

(a) Outer facilities (Bulwark, revetment)
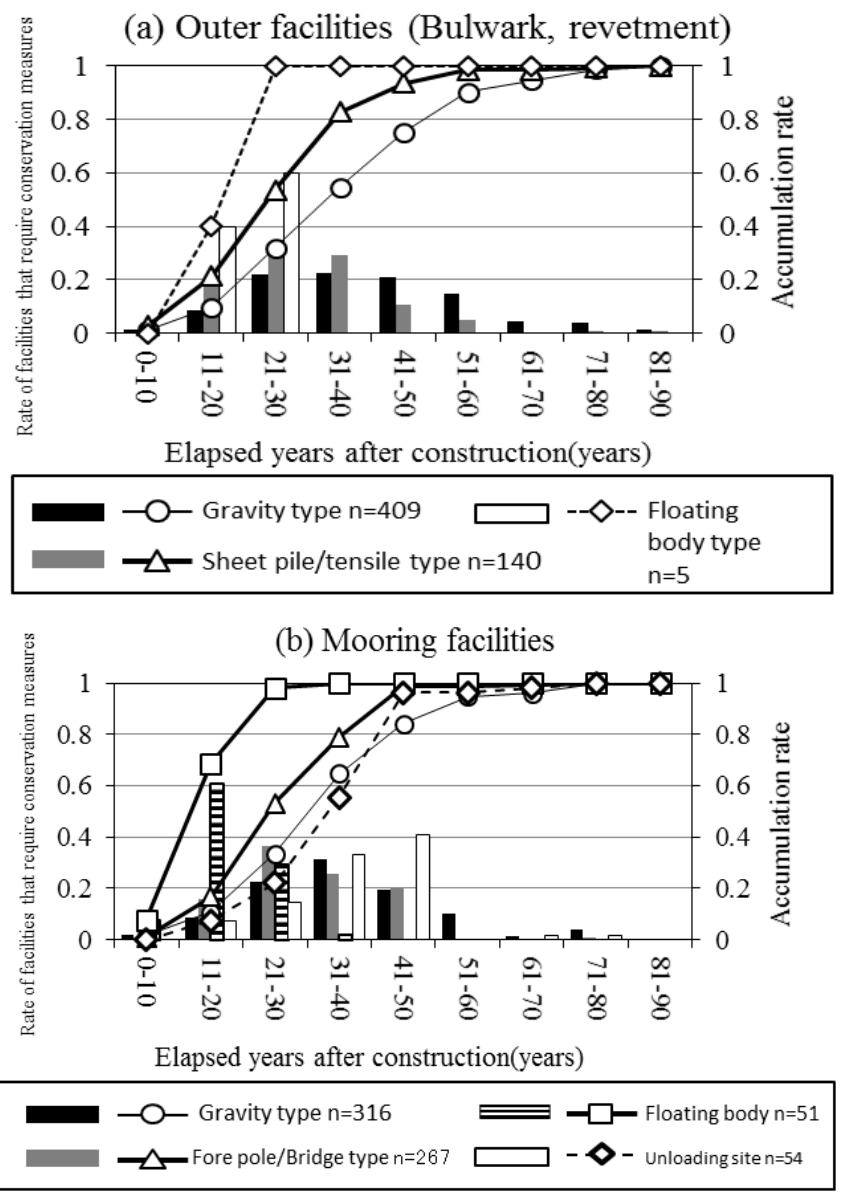

Fig. 3. Elapsed years after construction according to structural types.

The number of elapsed years after construction with reference to outer facilities, mooring facilities and transit facilities are shown in Fig. 2. While each facility of the number of years after construction necessary for conservation measures tended to increase in the rates between 21 and 30 years, the number of elapsed years after construction tended to be shortened in the transit facilities.

The numbers of years after construction of facilities that require conservation measures are shown in Fig. 3 with reference to the structural types.

Despite there are plenty of outer facilities with 21 to 30 years elapsed in either structural type, the rate of accumulation tended to be expedited in order of floating body type, fore pole/tensile type and gravity type. Mooring facilities tended to vary in order of gravity type $(31-40$ years), fore pole/bridge type ( 21 - 30 years) and floating body 
type $(11-20$ years $)$ and the floating body type tended to conspicuously be expedited in the rate of accumulation. Floating body type and fore pole/bridge type have plenty of steel structure in composition materials, due to plenty of plain concrete structure, the composition materials are considered to have effected on them.

From the above mentioned, the number of elapsed years in reference to facilities that require conservation countermeasures varies according to structural types, and those were assumed due to differences in constituent materials.

\section{2) The number of elapsed years after construction according to constituent materials}

Focusing attention on outer facilities and mooring facilities, the number of elapsed years after construction is indicated in Fig. 4. Furthermore, the constituent materials were classified into targeted each material (upper construction, main body construction, apron or the like) and also are indicated these major constituent materials (steel structure, reinforced concrete and plain concrete).

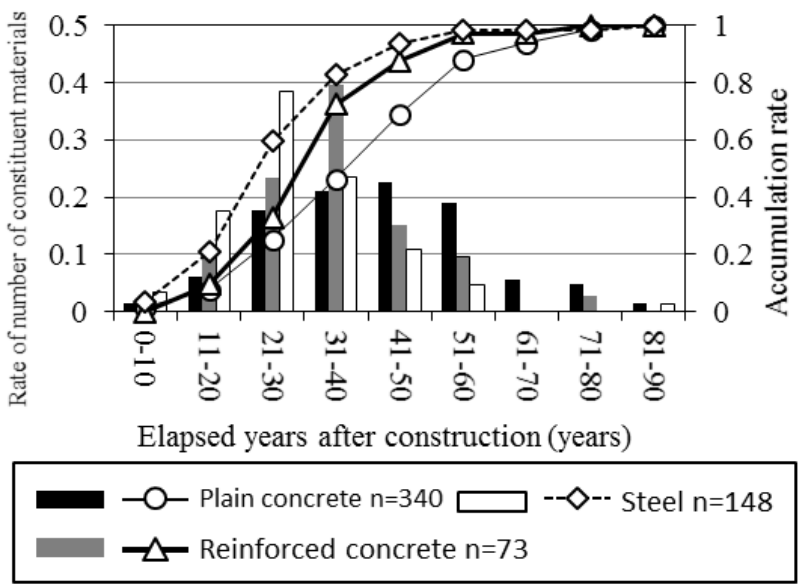

(a). Outer facilities (Bulwark, revetment).

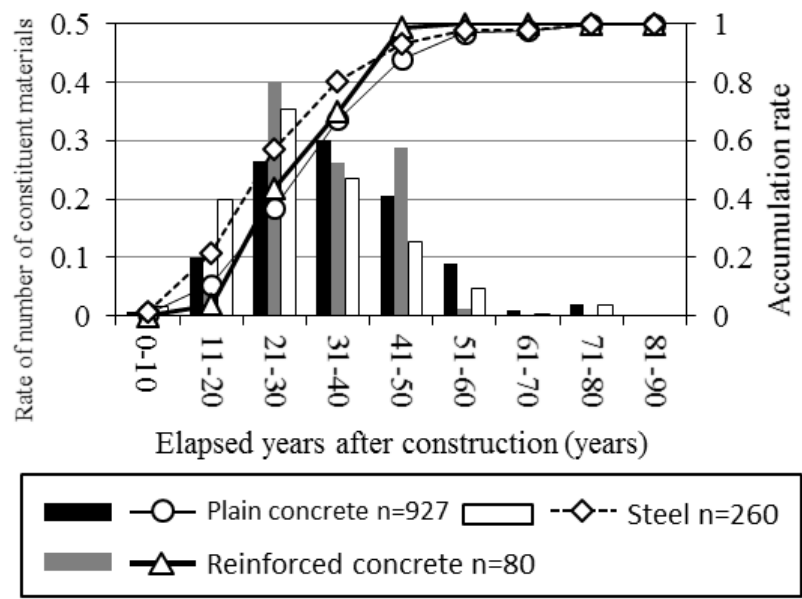

(b). Mooring facilities.

Fig. 4. Number of elapsed years after construction observed according to classes of materials.

Outer facilities whose timing for conservation countermeasure of steel structure was expedited more than other constituent materials, and the rate of 50 years after construction reached about $94 \%$ of total. Subsequently, it was followed by reinforced concrete (the rate of 50 years after construction was about $88 \%$ of total), plain concrete (the rate of 50 years after construction was $69 \%$ of all. With reference to outer facilities, the number of elapsed years after construction was conspicuously affected by the differences in constituent materials. Mooring facilities were liable to be similar despite they were not so pronounced as compared with outer facilities. Mooring facilities seemed to be affected by expeditious assumption for conservation countermeasures due to resulting interference when generating unevenness, bowlines and so forth.

Despite there are plenty of outer facilities with 21 to 30 years elapsed in either structural type, the rate of accumulation tended to be expedited in order of floating body type, fore pole/tensile type and gravity type. Mooring facilities tended to be varied in order of gravity type (31 - 40 years), fore pole/bridge type ( 21 - 30 years) and floating body type $(11-20$ years $)$ and the floating body type tended to conspicuously be expedited in the rate of accumulation. Floating body type and fore pole/bridge type have plenty of steel structure in composition materials, due to plenty of plain concrete structure, the composition materials are considered to have effected on them.

Viewing from the above, the number of elapsed years in reference to facilities required of conservation countermeasures varies according to structural types, and those were assumed due to differences in constituent materials.

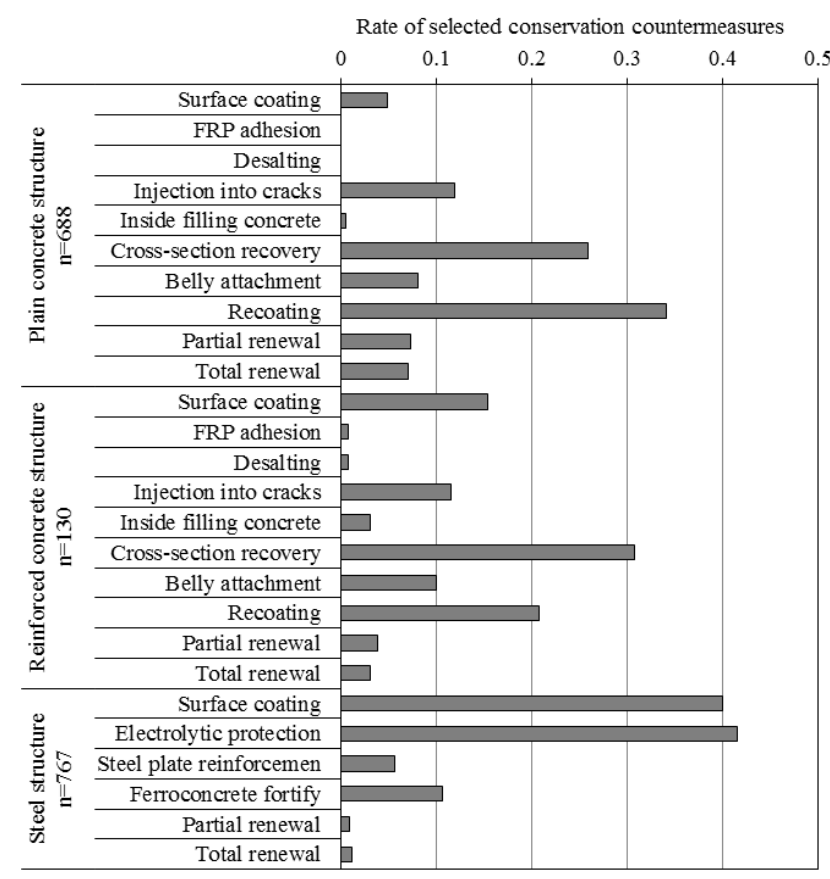

Fig. 5. Selected conservation countermeasure construction method (Outer facilities, mooring facilities).

\section{Selected Conservation Countermeasure Construction Method and Timing of Implementation}

\section{1) Selected conservation countermeasure construction method}

Focusing attention on outer facilities and mooring facilities, the selected construction methods, as a conservation countermeasure, were described respectively in accordance with constituent materials (see Fig. 5). For structures of plain concrete and reinforced concrete, selections of cross section renovation or recoating construction were frequent and for 
steel structures as a constituent material were tended to frequently select coating or galvanic protection method.

2) Timing of implementation for selected conservation countermeasures

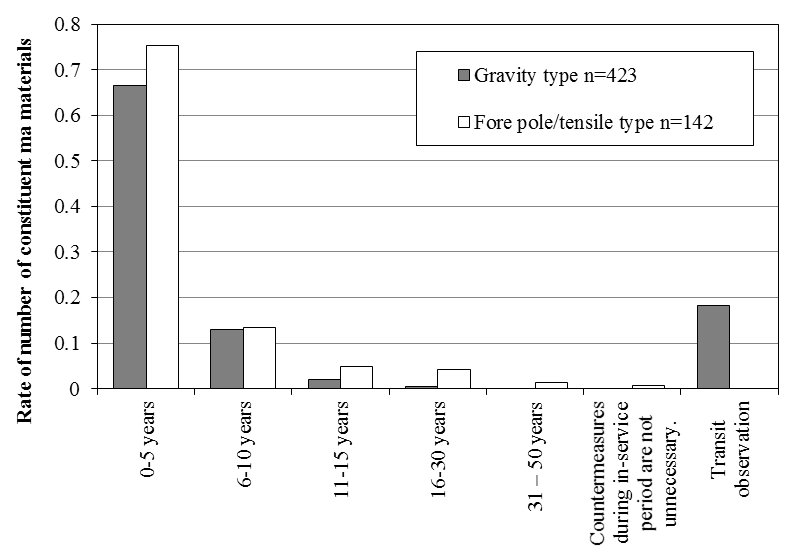

Fig. 6. Timing of conservation countermeasures for outer facilities (bulwark, revetment).

Of outer facilities, focusing attention on gravity type, fore pole/tensile type, showed an implementation timing (first time) of conservation measures for facilities that require conservation in (see Fig. 6.) In both structural types, facilities implementing conservation countermeasures within five years counted for more than half.

Moreover, fore pole and tensile type structures seemed the initial timing for countermeasures had widely been set compared with the in-service period (50 years from the formulation of the project). In steel structure this is affected by performing future aging forecasts from corrosion speed based on thickness measuring results, as in [6].

Meanwhile, gravity type structures, whose rate of facilities that require a follow-up test is about $20 \%$, and in particular, countermeasures after five years on tended to have almost none. This is caused by the condition of materials comprised of plain concrete for which an effective degradation forecasting method has not been established yet. However, in order to proceed with a strategic conservation control, forecasting the timing of conservation countermeasures and approximate expenses is crucial in view of decreasing contingent risks in accordance with an applicable aging forecasting method (for example, Markov chain model and useful life table method), after allowing uncertainty of forecast, as in [7].

\section{CONCLUSION}

In this version, putting the characteristics of the formulated conservation scheme in order, the following characteristics were determined: 1) Facilities that require conservation countermeasures count a lot of mooring facilities and transit facilities; 2) Conservation countermeasures for mooring facilities are prioritized; 3) The number of elapsed years of those after construction is affected by differences in constituent materials; 4) Steel structures are characterized by comparatively calculated conservation countermeasures.

In the meantime, the following assignments have been found: 5) preliminarily configure order priority according to restrictions on budget and utilization situation; (6) Introduce applicable degradation forecasting method in structural classes for which forecasting method has not been established yet to foresee the timing of conservation countermeasure and approximate expenses.

Inasmuch as the facilities for fishing ports so far have been ex-post conserving maintenance control, a calculated functional diagnosis has not been carried out. However, according to the implementation of the fisheries supply infrastructure functions conservation project, comprehension of degraded conditions for each facility seems to progress, as in [8].

Indicating degraded photo examples and plan formulation examples of fishing ports facilities, as well as adding function conservation plan document to newly be formulated, we are compiling technology reference documents for controllers of fishing ports contributing to plan formulations and to plan reevaluation.

In addition, this report is compiled from part of the content of the Fisheries Agency`s Fishery Infrastructure Improvement Entrusting Project "Performance Specifying Technology Deliberation Research Project of Fishing Ports Fishing Ground Facilities for fiscal 2012 year" by the authors.

\section{REFERENCES}

[1] N. Mikami, N. Asakawa, M. Hosaka, T. Mizuno, T. Kasai, and G. Nakanishi, "Research Concerning Efficient Fishing Port Maintenance by Maintenance Scheduling," Ocean Development Journal, vol. 25, pp. 1071-1076, 2009.

[2] N. Mikami, M. Hosaka, T. Mizuno, H. Umezu, N. Shiato, and T. Kasai, "Consideration of the cost reduction effects of stock management by case analyses for the functional maintenance projects of fishing port facilities," Japan Society of Civil Engineers Ocean Development Proceedings, vol. 26, June 2010.

[3] Fisheries Agency, Fishing Port List. [Online]. Available: http://www.jfa.maff.go.jp/

[4] Fisheries Agency, Fisheries Infrastructure Department, Guide for Function Conservation Planning (Draft). (2012). [Online]. Available: http://www.jfa.maff.go.jp/j/gyoko_gyozyo/g_hourei/pdf/tebiki121031 .pdf

[5] Fisheries Agency, Fisheries Infrastructure Department. [Online]. Available:

http://www.jfa.maff.go.jp/j/gyoko_gyozyo/g_hourei/pdf/gaidorain121 031.pdf

[6] Standards and Description of the Technical Facilities of the Port, Standards and the commentary Committee of technical facilities of the port, vol. 1, pp. 431-444, 2007

[7] N. Mikami, N. Asakawa, T. Fujita, T. Okano, T. Mizuno, and T. Kasai, "Application of the Stock Management and Proposal of Management System in the Fishing Port Facilities," Japan Society of Civil Engineers Ocean Development Proceedings, vol. 67, no.2 I-649-I-654, 2011.

[8] H. Umezu, H. Hayashi, and N. Mikami, "Amount of Construction in Fishing Port Facilities and The Need for Maintenance and Renewal of Facilities Function in the Future," Japan Society of Civil Engineers Ocean Development Proceedings, vol. 46, no. 2, 2009.

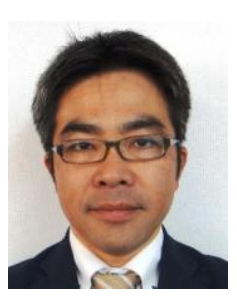

Takayasu Fujita was born in Kagoshima Pref. Japan He was Graduated from Kagoshima University in 1993. He received his master of fisheries from Kagoshima University in 1995, Kagoshima Japan. His major field of study is Fisheries.

$\mathrm{He}$ is working for FIDEC as a maintenance expert, 2-14-5 Tsukiji Chuo-ku Tokyo Met. Current and his previous research interests are fisheries and non-destructive diagnosis.

Mr. Fujita is member of JSCE, JCI 
Yasuhiro Yoshizuka was born in Fukuoka Pref. Japan. He was graduated from Kyusyu University in 1983 . He received his master of engineering from Kyusyu University in 1985, and Fukuoka Japan. His major field of study is fisheries infrastructure development.

$\mathrm{He}$ is working for FIDEC as a councillor, 2-14-5 Tsukiji Chuo-ku Tokyo Met. Current and previous research interests are fisheries infrastructure planning and design.

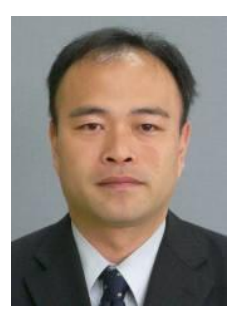

Takuya Kaneda was born in Okayama Pref. Japan. He was graduated from Osaka City University in 1997. He received his master of Engineering from Osaka City University in 1999, and Osaka Japan. His major field of study is Fishing port engineering.

$\mathrm{He}$ is working for Fisheries Research Agency as a maintenance expert of fishing port, 7620-7 Hasaki, Kamisu City, Ibaraki Pref, Japan.Current and previous research interests is non-destructive diagnosis.

Mr. Kaneda is member of JSCE, JCI.

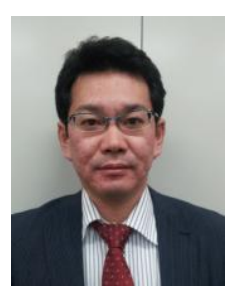

Masayuki Fudo was born in Hyogo Pref. Japan. He was graduated from Osaka city University in 1999. He received his master of engineering from Osaka city University in 2001, Osaka Japan. His major field of study is fisheries infrastructure development.

$\mathrm{He}$ is working for Fisheries Agency as Senior Specialist of fisheries infrastructure development, 1-2-1 Kasumigaseki Chiyoda-ku Tokyo Met. Current and previous research interests are fisheries infrastructure planning and design.

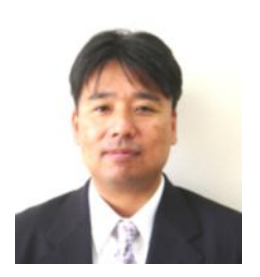

Shigeyuki Date was born in Fukuoka Pref. Japan. He was graduated from Nagasaki University in 1987 . He received his doctor of engineering, from Gumma University in 2005, Gumma Japan. His major field of study is Concrete Engineering, Maintenance Engineering.

He is working for Tokai Univ. as a professor of Dept. of Civil Engineering, 4-1-1 Kitakaname Hiratsuka Kanagawa Japan. Current and previous research interests Material design, Durability of Concrete structure, and Concrete production.

Dr. Date is member of JCI, JSCE, AIJ, and SMSJ. 